УДК 379.85

JEL classification: M39

Романова А. A.

канд. економ. наук

ORCID ID: 0000-0001-7336-1032

Жидок В. В.

канд. економ. наук

ORCID ID: 0000-0003-3706-9346

Забаштанська Т. В.

канд. економ. наук

ORCID ID: 0000-0002-5086-3651

Чернігівський національний технологічний університет

\title{
АДАПТАЦІЯ ФАХОВОЇ ОСВІТИ У СФЕРІ ТУРИЗМУ ДО ВИМОГ ТУРИСТИЧНОГО РИНКУ УКРАЇНИ
}

\section{ADAPTATION OF PROFESSIONAL EDUCATION IN TOURISM SPHERE TO THE REQUIREMENTS OF TOURISM MARKET IN UKRAINE}

Розвиток туристичної індустрії в Україні поступово набуває ринкових форм функціонування, тому основною умовою розвитку туристичного ринку є наявність фахівців, щзо володіють компетенціями щзодо використання специффічних технологій $i$ програмного забезпечення, застосування маркетингових інструментів для просування турпродуктів, володіння комунікативно-психологічними навичками спілкування 3 клієнтами, орієнтування у сучасних трендах розвитку індустрії гостинності, тощо.

У статті комплексно розглянуто загальні тенденції функиіонування національної системи вищої освіти Украӥни, щуо характеризується скороченням попиту на освітні послуги серед населення та зменшенням числа потенційних абітурієнтів; недостатнім фінансовим забезпеченням системи вищої освіти в цілому; мінливими вимоги на ринку праці Украӥни. Виявлено, щчо існуюча система підготовки фахівців у сфері туризму має вузько-направлений характер та в достатній мірі не відповідає економічному стану туристичної галузі та краӥни в иілому.

Узагальнено зарубіжний досвід щзодо планування навчального процесу у сфері туризму з врахуванням історичних, економічних і політичних умов. При ияьому тендениї формування змісту фахової туристичної освіти в нових сочіально-економічних умовах визначаються загальними рамками реформи національної системи вищої освіти Украйни, в ході якої, зокрема, відбувається зміна поколінь стандартів вищої освіти. Нове покоління освітніх стандартів надає більще можливостей закладам вищої освіти самостійно формувати зміст навчальних планів, вибіркових курсів і блоку дисциплін спеціалізації.

Для адаптації та фахового наповнення освітніх програм запропоновано внести зміни до переліку навчальних дисииплін, щзо демонструють мультидисциплінарний характер туризму відповідно до вимог туристичного ринку Украӥни.

Авторами обтрунтовано доцільність проведення комплексного дослідження туристичного ринку з метою визначення потреби у фахівиях відповідного профілю.

Ключові слова: туризм, сфера туризму, фахова вища освіта, заклади вищої освіти, дослідження туристичного ринку. 
The development of tourism industry in Ukraine has been gradually gaining the market forms of functioning, therefore the main condition for the development of the tourism market is the availability of specialists with expertise in using specific technologies and software, applying marketing tools for promotion of tourism products, possessing communicative and psychological skills of communication with clients, orienting in modern trends in the development of the hospitality industry, etc.

The article comprehensively examines the general tendencies of functioning of the national system of higher education in Ukraine, which is characterized by the reduction of demand for educational services among the population and the decrease in the number of potential entrants; insufficient financial support of the system of higher education in general; changing requirements in the labour market of Ukraine. It has been found out that the existing system of training specialists in the field of tourism has a narrow specialization character and does not adequately correspond to the economic situation in the tourism industry and in the country in general.

The foreign experience in planning the educational process in the field of tourism, taking into account historical, economic and political conditions, has been generalized. At the same time, the tendencies of the formation of the content of professional tourism education in the new socioeconomic conditions are determined by the general framework of the reform of the national system of higher education of Ukraine, during which, in particular, there is a change of generations of standards of higher education. The new generation of educational standards provides more opportunities for institutions of higher education to independently formulate the content of curricula, selective courses and a block of disciplines of specialization.

For adaptation and professional filling of educational programs it has been proposed to make changes to the list of educational disciplines demonstrating the multidisciplinary nature of tourism in accordance with the requirements of the tourism market of Ukraine.

The authors have substantiated the necessity of conducting a comprehensive study of the tourism market in order to determine the need for specialists of the corresponding profile.

Keywords: tourism, tourism sphere, professional higher education, institutions of higher education, tourism market research.

Вступ. Туристична індустрія відіграє визначальну роль в культурному, соціальному та економічному розвитку будь-якої країни. Ефективність функціонування туристичної індустрії визначається не тільки інфраструктурними та маркетинговими складовими, а й, перш за все, кадровим потенціалом, високим рівнем професіоналізму працівників туристичної сфери.

Сучасну сферу туризму можна охарактеризувати як розгорнуту систему секторів. Це управління туристичною діяльністю в регіонах; надання окремих послуг туристам; створення та популяризація турпродуктів; а також посередництво в їх реалізації; консультаційні, інвестиційні послуги, в тому числі підготовка кадрів для туристичних підприємств. У рамках цієї системи спостерігається тенденція мобільності кадрів. Фахівці переходять 3 одного сектора в інший, забезпечуючи стійке функціонування всієї туристичної індустрії. Подібна тенденція формує вимоги до стандарту якості туристичного обслуговування як ключового виду професійної діяльності. 
Проблеми якості фахової освіти у сфері туризму набувають все більш вагомого характеру і привертають увагу багатьох вітчизняних науковців: Г.В. Балабанов [2], О.О. Любіцева [5], С.М. Мархонос, С.В. Мельник, М.А. Молочко, В.О. Ткач, В.К. Федорченко, Л.І. Шпак [11]. Найбільш гостро стоїть проблема стандартизації якості вищої фахової освіти з туризму.

Постановка завдання. Метою даної статті є визначення засад адаптації фахової освіти у сфері туризму до вимог туристичного ринку України шляхом формування системи підготовки професійних кадрів, що сприятиме підвищенню якості та конкурентоспроможності туристичної галузі України.

Методологія дослідження. У процесі дослідження були використані комплексний підхід, метод аналогій, аналізу і синтезу, порівняльний аналіз, економіко-статистичний, графічний, логічний методи та ін.

Результати дослідження. Розвиток туристичної індустрії в Україні поступово набуває ринкової форми функціонування, тому основною вимогою ринку праці стає наявність фахівців, що мають компетенції щодо використання специфічних технологій i програмного забезпечення, застосування маркетингових інструментів для просування турпродуктів, володіння комунікативно-психологічними навичками спілкування з клієнтами, орієнтування у сучасних трендах розвитку індустрії гостинності, тощо.

Методологічна основа побудови якісної безперервної системи фахової освіти в галузі туризму повинна враховувати національні, європейські і світові тенденції розвитку, структурні зміни в ринковій економіці та соціальній політиці держави. Головними особливостями освіти в галузі туризму повинні виступати: надання свободи у виборі освітніх траєкторій у відповідності до власних запитів особистості і можливостей працевлаштування на ринку праці; врахування потреб ринку праці та туристичного ринку - замовників професійних туристичних кадрів, забезпечення свободи діяльності освітніх установ для формування оригінальних і різноманітних освітніх програм, у тому числі, регіональних.

М. Портер у своєму фундаментальному дослідженні конкурентних переваг націй зробив висновок: «Освіта і навчання відіграють вирішальну роль при формуванні національної конкурентної переваги. Досягнення більш складних конкурентних переваг і ведення конкуренції в передових сегментах та нових галузях вимагає людських ресурсів, що володіють все більш високим рівнем кваліфікації та здібностей. Якість людських ресурсів повинна постійно підвищуватися, якщо прагнути до підвищення рівня розвитку економіки країни» [1].

Однак перед сучасним суспільством постають виклики на національному рівні щодо розвитку системи освіти та підготовки висококваліфікованих кадрів 
Кон'юнктура ринку праці повинна формувати номенклатуру спеціальностей і професій. На цьому рівні, в основному, і виникають складнощі щодо побудови концепцій профільних систем освіти. На сучасному етапі становлення ринку освітніх послуг України пропозиції закладів вищої освіти (ЗВО) перевищують попит суспільства на освітні послуги, а якість яких не відповідає вимогам сучасності [2].

На підставі проведених досліджень [3] до загальних тенденцій функціонування та розвитку національної системи вищої освіти України слід віднести:

- скорочення числа потенційних абітурієнтів в цілому через демографічний спад у країні;

- скорочення попиту серед населення на отримання вищої освіти;

- збільшення попиту на робітничі професії;

- мінливі та динамічні вимоги на ринку праці;

- зменшення фінансового забезпечення системи вищої освіти в цілому;

- «ваучерний» принцип розподілення бюджетного фінансування, що підсилює загрозу функціонування регіональних закладів вищої освіти.

Висока якість освіти - головна мета освітніх установ України, що готують фахівців для туріндустрії. Освітня система в сфері туризму тільки формується, вона також молода, як і сама галузь туризму.

Виявлено, що поряд 3 широко поширеними формами туристичної діяльності - туроператорська (формування туру), турагентська (продаж туру) та обслуговування туристів під час подорожей (екскурсійне та готельноресторанне обслуговування) - в останні роки з'явилися супутні напрямки туристичної діяльності, що пов'язані з організацією подорожей, розробкою програм регіонального розвитку туризму, формуванням принципово нових туристичних продуктів i просування їх як на вітчизняному, так i на міжнародному ринках. Останнє особливо актуально для сучасних умов розвитку туріндустрії в нашій країні. Поки що спостерігається; істотне порушення балансу в туристичних потоках на користь виїзду за кордон, ніж розвитку в'їзного та внутрішнього туризму.

Аналіз кадрового потенціалу підприємств туристичної галузі показує, що за рідкісним винятком працівники туристичних фірм або взагалі не мають спеціальної освіти або пройшли навчання на короткострокових комерційних курсах. 3 огляду на ситуацію, що склалася, перед державою стоїть одне 3 найскладніших завдань щодо проведення галузевої реформи в туризмі створення системи підготовки кадрів за всіма рівнями вищої освіти відповідно до вимог міжнародних стандартів і розробка в зв'язку 3 цим відповідної національної програми.

Очевидним є, що існуюча система підготовки кадрів має вузьконаправлений характер та не відповідає економічному становищу туристичної 
галузі та країни в цілому. Спеціальність 242 «Туризм», за якою здійснюється підготовка здобувачів вищої освіти, віднесено до галузі знань 24 «Сфера обслуговування» [4]. До сфери обслуговування належать: торгівля, громадське харчування i невиробничі галузі. Невиробнича сфера, що задовольняє різноманітні потреби населення в цілому, крім виробництва матеріальних благ, включає: житлово-комунальне та побутове обслуговування населення; транспорт, зв'язок, соціальне забезпечення, а також соціально-культурний сервіс i туризм. Водночас туристична галузь покриває виконання ще й соціально-відповідальної функції 3 налагодження взаємовигідних партнерських відносин між усіма суб'єктами туристичного ринку, а також економічної функції з виробництва туристичних продуктів та послуг.

Основними завданнями економічної діяльності в туристичній галузі є:

- створення турпродукту;

- надання туристичних послуг;

- формування ринку туристичних послуг;

- вдосконалення туристичної інфраструктури;

- розвиток внутрішнього та міжнародного туризму.

Таким чином, сфера обслуговування звужує сприйняття туризму лише як надання окремих послуг [5]. Туризм повинен розглядатись як вид економічної діяльності, галузь бізнесу.

Бурхливий розвиток туристичної індустрії викликав необхідність підготовки великої кількості висококваліфікованих кадрів 3 широким спектром професійних знань, умінь та навичок. Ситуація, що склалася вимагає змінити (зменшити/збільшити) не лише ліцензійні обсяги підготовки фахівців в галузі туризму, а й професійну спрямованість закладів вищої освіти, що готують туристичні кадри, в залежності від формування та функціонування туристичного ринку окремого регіону.

Проаналізуємо взаємозалежність між туристичною активністю та інтенсивністю підготовки фахівців з туризму в кожному регіоні України. Як індикатор туристичної активності візьмемо показник туристичного збору. Цей місцевий збір обраховується та включається в оплату у випадку, якщо клієнт закладу розміщення вказав у картці реєстрації мету свого перебування «туризм» [6].

Для того, щоб результати були репрезентативні та порівняльні, за основу обрано саме області, а не міста. Як видно з рисунку 1 областями з найбільшим обсягом туристичного збору за даними 2017 року є Київська (18 млн грн) та Львівська (10,7 млн грн). Саме в цих регіонах присутня найбільша кількість ЗВО, які готують фахівців у сфері туризму: 33 та 17 освітніх установ відповідно.

Зокрема, у Херсонській області спостерігається невідповідність між обсягом туристичного збору (2,7 млн грн) та кількістю ЗВО (лише три освітні 
установи) з підготовки фахівців досліджуваного напряму. Високі обсяги туристичного збору пов'язані зі стихійним напливом відпочиваючих влітку у зв’язку з анексією Автономної республіки Крим.

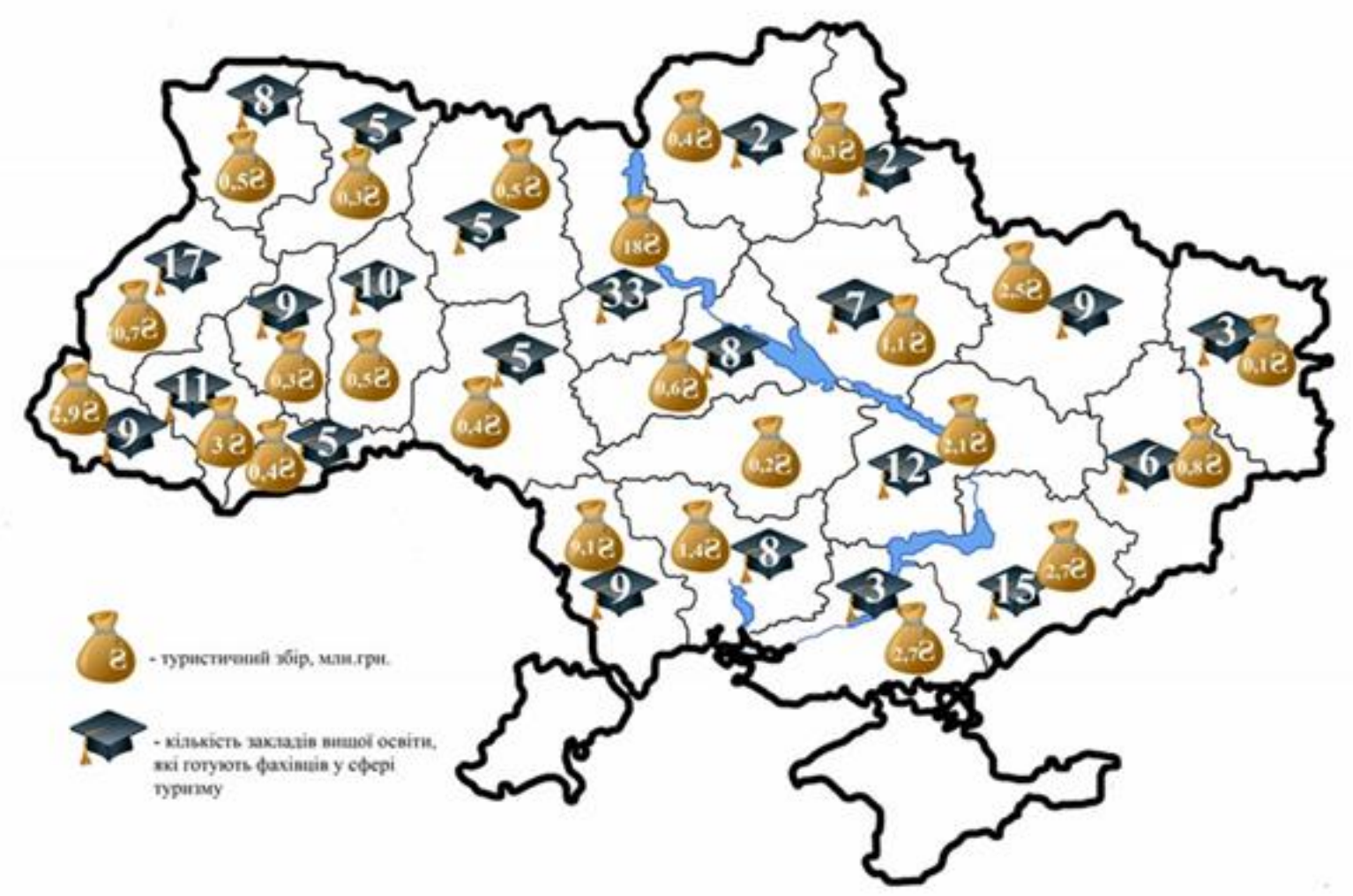

Рисунок 1 - Показники туристичного збору та кількості закладів вищої освіти, що готують фахівців у сфері туризму за 2017 рік *систематизовано та узагальнено за даними Державної служби статистики України [7].

Значна кількість ЗВО, що готують фахівців у сфері туризму в Хмельницькій (10), Тернопільській (9) та Волинській (8) областях при незначних надходженнях туристичного збору від 0,5 млн грн до 0,3 млн грн. Це пояснюються тим, що випускники ЗВО зазначених областей працевлаштовуються у Львівській області - флагмана туристичного ринку Західного регіону України.

У Чернігівській області лише два ЗВО готують фахівців туристичної сфери при обсязі туристичного збору 0,4 млн грн. Враховуючи значний туристичний потенціал області ці показники є дуже низькими. Схожа ситуація і в Сумській області - маємо 0,3 млн грн туристичного збору і лише два 3ВО, що готують профільних фахівців. Навіть в Луганській області при найнижчому обсязі туристичного збору, біля 0,1 млн грн, фахівців у сфері туризму готують три ЗВО. На жаль у Кіровоградській області жоден ЗВО не займається підготовкою профільних фахівців туристичної сфери. 
Враховуючи нерівномірний характер розміщення по території України 3ВО, що здійснюють підготовку фахівців у галузі туризму, доцільно провести комплексне дослідження ринку праці у сфері туризму та курортів 3 метою визначення потреби у фахівцях відповідного профілю, враховуючи методологічну базу авторитетних міжнародних організацій (UNWTO, European Travel Commission).

Проведене дослідження має налагодити взаємозв'язок між всіма суб'єктами туристичної діяльності: владою, бізнесом та освітою, для задоволення кадрових потреб реального сектору економіки у висококваліфікованих фахівцях відповідної сфери.

Сучасна система вищої освіти в Україні відчуває сильний вплив досвіду західних країн щодо підготовки фахівців у сфері туризму та гостинності [8]. 3 огляду на те, що організація туристичної діяльності немає сенсу без розуміння глобальної ситуації в туріндустрії, природно, що вивчення зарубіжного досвіду освіти і практики є вкрай важливим.

У силу цілого ряду історичних, економічних і політичних умов у різних країнах сформувалися різноманітні моделі до планування освітнього процесу у сфері туризму. Розглянемо британську, канадійську, американську та німецьку освітні моделі [9].

Великобританія вважається однією 3 перших країн світу, де системно почали готувати фахівців індустрії гостинності. Британська модель ілюструє два відмінні підходи до навчання гостинності. Перший підхід представлений на більш низьких освітніх рівнях (середньо-спеціальному, професійнотехнічному), де програми більш професійно орієнтовані та призначені для забезпечення студентів конкретними, практичні навичками в сфері гостинності. Зазвичай кількість доступних програм i загальна кількість студентів, які навчаються за цими типами курсів, $є$ більшою, ніж на класичних академічних програмах. Другий підхід вивчення гостинності пропонується сектором вищої освіти та зосереджується на забезпеченні студента комплексом інструментів, які розвивають аналітичні здібності. Як правило, ці освітні програми розраховані на чотири роки i, майже без винятку, один рік (або більш тривалий період) має бути присвячено стажуванню в туристичній галузі.

Фаховий рівень освітніх програм 3 туризму у Канаді інтегрований до найнижчого рівня післядипломної освіти та представлений переважно курсами гостинності, а також іншими дисциплінами, пов'язаними 3 туристичною індустрією. Навчальні курси концентруються на забезпеченні туристичної галузі оперативним персоналом, а що стосується керівних кадрів у туризмі, то освітні програми почали створюватися відносно недавно, на початку 2000-них. Таке зволікання пояснюється невизначеністю попиту, відсутністю інтересу 
серед роботодавців та загальним протистоянням більш широко розвинутим ринком освітніх туристичних програм у вишах США.

У США дослідження менеджменту гостинності та туризму інтегровані у вищу та безперервну освіту. Туристичні освітні програми в США поділяються на два типи: перший здійснюється шляхом академічної освіти на основному та післядипломному рівнях, де пропонується туризм як окрема спеціальність або де він $є$ частиною програми, обраної студентами. Існує більш як 30 університетів, бізнес-шкіл та коледжів в США, які на даний час здійснюють у такий спосіб підготовку фахівців з туризму. Ці програми розраховані, як правило, на чотири роки, а їх зміст доволі розлогий. В основному навчальні плани складаються з традиційного основного навчального плану, пов'язаного 3 гостинністю чи рекреаційно-курортною справою. Другий підхід реалізації туристичної освіти в США базується на забезпеченні професійного розвитку за допомогою сертифікованих програм, призначених для тих, хто вже працює в галузі на управлінському рівні. 3 точки зору залучення реального сектору економіки, то в цих програмах це, як правило, має форму професійного стажування, що складається 3 12-16 тижнів повної зайнятості або шести місяців часткової зайнятості (без відриву від основного місця роботи).

Освіта в галузі управління туризмом у Німеччині здійснюється шляхом поєднання курсів денної та заочної форми навчання та вищого рівня освітніх програм, які надаються навчальними закладами на трьох різних ступенях. Поперше, існують освітні установи, які забезпечують початковий рівень знань. Рівень ділових навичок у туристичній індустрії формується на дворічних курсах, що пропонують кваліфікацію, необхідну для доступу до вищої освіти у сфері туризму. По-друге, існують вищі професійні коледжі, в яких вкладаються три- або чотирирічні курси з туризму, подорожей та готельного управління. Освітні програми 3 туризму, що пропонуються на університетському рівні, - це чотирирічні бізнес-орієнтовані економічні курси, які поєднують вивчення бізнес-досліджень зі спеціалізацією туризму. Вони як правило, включають наступні основні елементи: загальну економіку, право, фінансовий менеджмент, математику, маркетинг, управління бізнесом, управління персоналом, оподаткування та іноземні мови. Співвідношення між цими дисциплінами істотно відрізняється у різних навчальних закладах. I нарешті, існують університети та професійні установи, що пропонують (в основному) аспірантуру у вигляді одного року навчання на повний робочий день або трьох років за сумісництвом.

У той же час в Україні підготовка за туристичними спеціалізаціями не в повній мірі відповідає сучасним вимогам туристичного ринку через обмежений обсяг навчального часу на дисципліни спеціалізації і завеликого часу на цикли загальних і спеціальних дисциплін. 
Запропонований на рис. 2 перелік курсів та дисциплін демонструє мультидисциплінарний характер туристичної сфери, що потрібно враховувати при гармонізації кваліфікаційних вимог професійної підготовки та навчальних програм у сфері туризму в ЗВО. Для постійного коригування навчальних програм та підвищення кваліфікації науково-педагогічного персоналу необхідно моніторити тренди туристичної індустрії та потреби туристів.

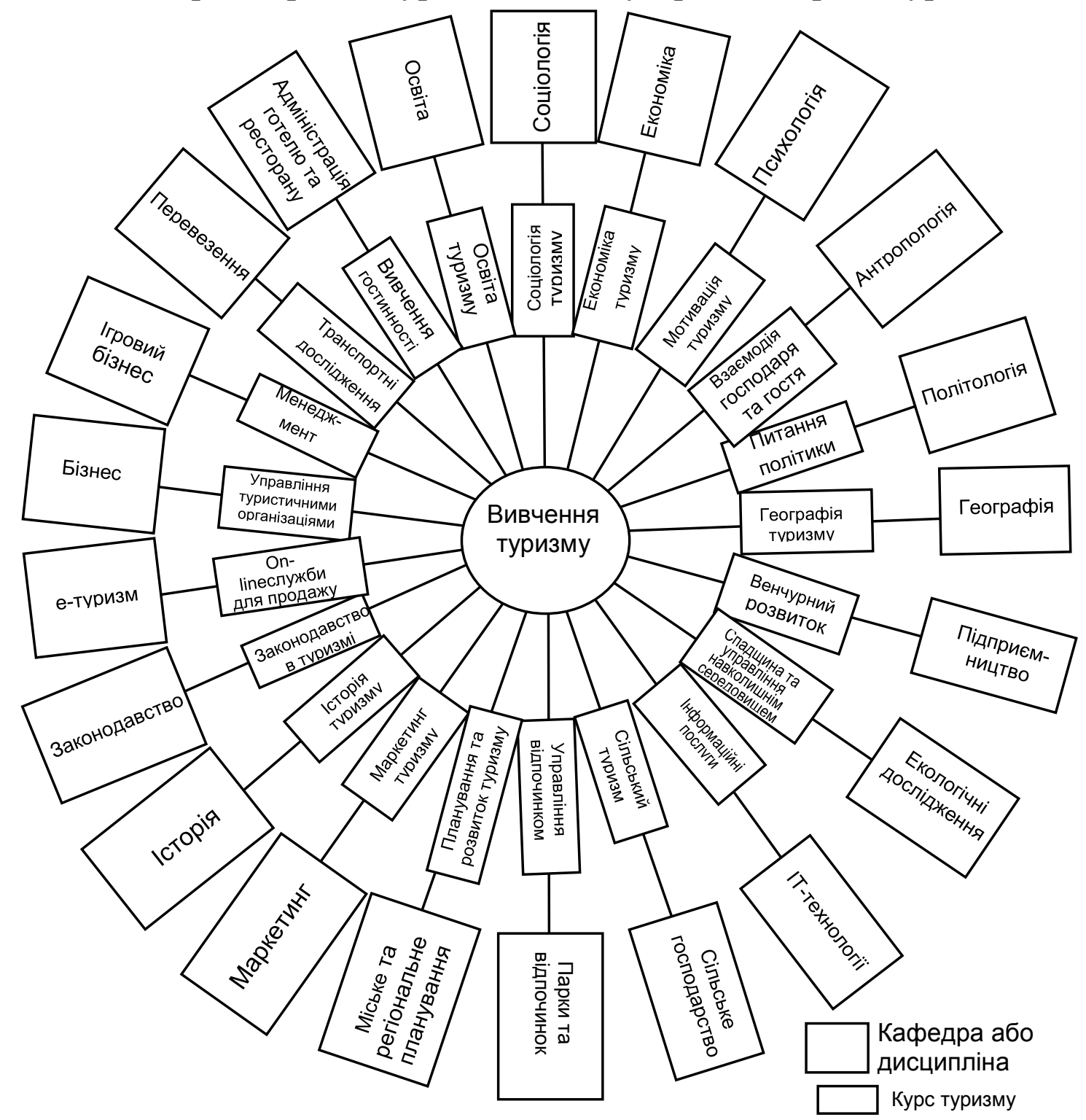

Рисунок 2 - Дисципліни та підходи для здобуття кваліфікаційних навичок фахівців у галузі туризму

* адаптовано Джафар Джафарі, Університет Вісконсін [10].

Тенденції формування змісту фахової туристичної освіти в нових соціально-економічних умовах визначаються загальними рамками реформи вищої освіти України, в ході якої, зокрема, відбувається зміна поколінь стандартів вищої освіти. Нове покоління освітніх стандартів надає більше 
можливостей 3ВО автономно формувати зміст навчальних планів, вибіркових курсів і блоку дисциплін спеціалізації.

Стандарти туристичної освіти України, що були затверджені в 2010 році, втратили чинність. Натомість проект стандарту вищої освіти другого магістерського рівня за спеціальністю 242 «Туризм», який було розроблено науково-методичною комісією 3 транспорту і сервісу ще у 2016 році, досі залишається не затвердженим Міністерством освіти і науки України.

При формування освітніх стандартів на засадах компетентнісноорієнтованого підходу [11] компетентність є базовим поняттям стандарту, що відповідає за формування достатнього обсягу знань, навичок та досвіду у певному виді діяльності. У проекті стандарту вищої освіти підготовки фахівців в сфері туризму визначено перелік компетентностей випускника (інтегральних, загальних та фахових) та узагальнено результати навчання, що визначають нормативний зміст підготовки здобувача вищої освіти у пізнавальній, емоційній та психомоторній сферах [12].

Але професійна туристична освіта за визначеними компетентностями для майбутніх фахівців туріндустрії має певні недоліки. Здобувачі вищої освіти в першу чергу прагнуть оволодіти практичними навичками в туристичний діяльності, а ЗВО намагаються забезпечити освітній процес на теоретичній основі. Тобто основною проблемою вищої освіти в сфері туризму $\epsilon$ відірваність теоретичної бази від практичної діяльності, низька взаємодія освітніх установ та підприємств туристичної галузі.

Висновки. Таким чином, до загальних рекомендацій щодо підвищення якості та конкурентоспроможності української туристичної індустрії варто віднести комплексне дослідження туристичного ринку та ринку праці з метою визначення потреб у фахівцях відповідного профілю; гармонізацію стандартів вищої освіти в галузі туризму, розробку освітніх програм та формування базових компетентностей фахівців у сфері туризму з урахуванням виявлених потреб.

Перспективами подальших наукових розробок має бути формування пропозицій щодо налагодження стабільної співпраці між всіма суб'єктами туристичної діяльності: владою, бізнесом та закладами вищої освіти, що забезпечують підготовку фахівців в галузі туризму та гостинності, задля задоволення кадрових потреб реального сектору економіки.

\section{Література:}

1. Портер М. Конкурентна перевага: Як досягти високого результату і забезпечити його стійкість / пер. $з$ англ. М. : Альпіна Бізнес Букс, 2008. 715 с.

2. Балабанов Г. В., Гришко Р. О. Сучасний стан національного ринку вищої професійної освіти у галузі туризму. Географія та туризм. Київ, 2014. Випуск 28. URL: http://www.geolgt.com.ua/images/stories/zbirnik/vipusk28/v283.pdf

3. Системний маркетинг: сучасні аспекти : колективна монографія / під заг. ред. В.В. Жидок. Чернігів : ЧНТУ, 2016. С. 228-229. 
4. Про затвердження переліку галузей знань і спеціальностей, за якими здійснюється підготовка здобувачів вищої освіти: Постанова Кабінету Міністрів України від 29.04.2015 № 266 / Офіційний портал Верховної Ради України. URL: http://zakon5.rada.gov.ua/laws/show/266-2015-\%D0\%BF.

5. Любіцева О.О. Проблеми фахової освіти в туризмі. Географія та туризм : Наук. зб. К.: Альтерпрес, 2010. Вип. 8. С.109-113.

6. Romaonova A. A., Zhydok V. V., ZabashtanskaT. V. Market research of inbound tourists in Chernigov as a factor of increasing tourist attractiveness. Науковий вісник Полісся. 2017. № 2 (10). Ч. 1. C. 216-228.

7. Державна служба статистики України: офіційний сайт. URL: http://www.ukrstat.gov.ua.

8. Романова A.A. Global trends of tourism development / Глобальные тенденции развития туризма. Вісник Київського начіонального торговельно-економічного університету. Київський національний торговельно-економічний університет, 2017. №6 (116). С. 32-42.

9. Cooper Ch., Shepherd R.,. Westlake J. Educating the educators in tourism: a manual of tourism and hospitality education. Published by the World Tourism Organization. Madrid. 1996. URL: https://www.e-unwto.org/doi/pdf/10.18111/9789284401512.

10. Jafari J. Tourism Social Science. Annals of Tourism Research. University of Wisconsin Stout, McIntosh and Goeldner. 1991. 18(1): 1-9.

11. Шпак Л. І. Проблеми кадрового забезпечення туристичної галузі в системі компетентнісно-орієнтованого підходу. Науковий часопис НПУ імені М.П. Драгоманова. Серія 18 : Економіка i право. 2015. Вип. 27. С. 103-109 URL: http://nbuv.gov.ua/UJRN/Nchnpu_018_2015_27_16.

12. 242 Туризм: проект Стандарту вищої освіти / М-во освіти і науки України. URL:https://mon.gov.ua/ua/osvita/visha-osvita/naukovo-metodichna-rada-ministerstva-osviti-inauki-ukrayini/proekti-standartiv-vishoyi-osviti. 